\title{
An Evaluation of Marine Sediments in Terms of their usability in the Brick Industry: Case Study Port of Koper
}

\author{
Patrik Baksa', Franka Cepak², Rebeka Kovačič Lukman ${ }^{3}$, Vilma Ducman ${ }^{* 4}$ \\ ${ }^{1}$ Port of Koper d. d., Vojkovo nabrežje 38, SI-6501 Koper, Slovenia \\ e-mail: Patrik.Baksa@luka-kp.si \\ ${ }^{2}$ Port of Koper d. d., Vojkovo nabrežje 38, SI-6501 Koper, Slovenia \\ e-mail: Franka.Cepak@luka-kp.si
}

${ }^{3}$ Faculty of Energy Technology, University of Maribor, Hočevarjev trg 1, SI-8270 Krško, Slovenia e-mail: RebekaKovacic3@gmail.com

${ }^{4}$ National Building and Civil Engineering Institute, Dimičeva ulica 12, SI-1000 Ljubljana, Slovenia e-mail: Vilma.Ducman@zag.si

\begin{abstract}
A dredging process is essential for the development of harbours and ports, allowing the functional daily operation of the port. The management of dredged material represents a worldwide challenge, especially considering unwanted deposition of material. Because of their chemical, petrographic, mineralogical and homogeneity composition, marine sediments could represent an appropriate raw material for the brick industry, particularly for the production of clay blocks, roofing and ceramic tiles. In this study dredged material from Port of Koper was tested for such use, thus various analyses were carried out in order to determine if the dredged material is environmentally friendly and suitable for use in the brick industry. These included: chemical analysis, mineralogical analysis, particle size analysis, chloride content analysis and tests of firing in a gradient furnace. Furthermore, tests of mechanical properties, as well as tests of the frost-resistance of the samples were carried out. On the basis of the primary analyses and samples prepared in a laboratory, it was confirmed that marine sediments from the Port of Koper, without any additives are only conditionally suitable as a source material for producing brick products, because without additives they exhibit too much shrinkage on drying and firing, as well as high water absorption, this can be improved by the incorporation of suitable additives, for example, virgin clay or other suitable waste material. The approach described herewith can also be followed to assess sediments from other ports and rivers regarding its potential use in clay brick sector.
\end{abstract}

\section{KEYWORDS}

Marine sediment, Dredging, Recycling, Clay bricks, Chemical analysis, Mechanical properties.

\section{INTRODUCTION}

Dredging operations are necessary to maintain navigation in waterways and access to harbours. Each year, 100 million tonnes of material are dredged around the world and

\footnotetext{
* Corresponding author
} 
could contain various materials from rocks to clays with different amount of organic matter and types of contaminants [1]. Thus, sediments represent a heterogeneous type of material with specific characteristics, which differ from region to region. In order to determine further usage of dredged material and its monitoring, the research of its characteristics must be carried out [2]. Mymrin et al. [3] report that in the USA alone, approximately 2.4 million $\mathrm{m}^{3}$ dredged per year is to be disposed in years between 2011 and 2018, claiming that disposal of large amounts of materials dredged will cause new environmental problems. As reported by Couvidat et al. [4] dredged sediments are in most cases disposed, storing materials in landfill sites, which is costly and requires constant monitoring. Dubois et al. [1] also argue that dumping sediments from the sea are constrained by national and international regulations.

The biggest Slovenian port - the Port of Koper also carries out dredging operation to deepen the Basins 1, 2 and 3, and expecting to obtain around $300,000 \mathrm{~m}^{3}$ of material, which is planned to be deposited at the three cassettes located in Ankaranska Bonifika [5], and could indicate environmental problems. Thus, treatment and reuse of material is encouraged also by the European guidelines, however, applications are still very limited [6]. Several studies suggested that the dredged materials have a possibility to be used as a resource in the construction industry, e.g. usage for brick production [7], as a composite construction material [3], in the process of manufacturing concrete [8] or reusing the marine sediments as a partial replacement material in the paving blocks in order to improve the properties and reduce the costs [9]. Another possible usage of the dredged material is for creation of habitat, e.g. creation of artificial reefs and shoals, filling dead-end basins and canals and remediation of landfills [10]. The Sinclair Knight Merz study [11] discusses alternatives for dredged material in the reclamation processes, and also Li et al. [12] demonstrated a production of environmental friendly earth fill from dredged marine sediments.

The dredged material is a valuable resource although much of it is currently disposed of because of economic and logistical constraints [13]. In many countries, disposal is not desirable anymore because of a lack of disposal areas as well as environmental concerns. Sheehan [14] argues that beneficial use of dredged material allows an implementation of new and innovative management procedures, minimizing environmental impacts. As mentioned, an alternative option of the dredged material usage is in the production of clay bricks. Various waste materials can be incorporated into the production of clay bricks, improving the shaping technical parameters of the products and decreasing energy usage within the production processes and consequently environmental impact [15]. Also additives, such as sludge waste bring advantages in the clay brick production from technical perspective [16] or other waste materials, improving the clay brick properties [17]. Further experiments, e.g. Mazen et al. [18] were performed by usage of polluted river sediments after treatment in the brick production processes on a factory scale. Mezencevova et al. [19] reported that a replacement of 50\% of raw material with dredged sediments in brick production caused no anomalies in physical and chemical characteristic of such bricks. Xu et al. [20] as well, claimed that the dredged sediments in the brick production is promising and showed that there are no barriers to use river sediments as secondary raw materials for the brick production processes. Another study by Cappuyns et al. [21] examine also consumers' perspective regarding the usage of the bricks from dredged sediments, where consumers are rather suspicious of bricks produced from dredged materials, which is mainly due to the lack of relevant information available.

However, in comparison to river sediments, marine sediments contain a higher amount of chlorides, also, they are often more polluted by heavy metals [22]. In the process of deciding how to treat and use the dredged material, it is crucial to evaluate its geo-mechanical and environmental characteristics. Sediments obtained by dredging are 
mainly composed of sand, clay fraction and seawater, and can also include various contaminants with a range of hazardous properties [6]. In the case of using dredged material as a secondary raw material, it is necessary to process it technologically. The technological treatment depends on the purpose of the final material. It is often necessary to use additives and other waste, such as paper sediment, ash, flint, etc. in order to meet the relevant parameters for shaping, and to achieve the necessary final material properties. The firing process usually causes immobilization of the heavy metals so that they no longer pose a potential threat to the environment, which is an additional benefit in cases where sediments contain heavy metals in excessive concentrations.

The goal of this research was to make an assessment whether specific dredged material can be of use in clay-based sector and thus avoid landfill deposits and producing valuable materials for further use in the construction industry. To achieve the goal, specific analyses of the sediments obtained by the dredging process from Port of Koper were carried out. These studies were comprised of the analyses of marine sediment content (content of the clay and the suitability for the brick production), including chemical analysis, mineralogical analysis, particle size analysis and chloride content. Furthermore, ceramic-technological tests of clay were carried out to determine linear shrinkage, water absorption, compressive and flexural strengths of the experimental samples fired at selected temperatures. The mechanical properties as well as water absorption and frost resistance of the final product were investigated in order to define the optimal characteristics of newly developed products. It was expected that the final product will be a brick, used in the construction sector for building purposes.

\section{MATERIALS AND METHODS}

The methods used in the study consisted of experimental methods carried out in the laboratory followed by data analyses and syntheses, as well as a sampling method to obtain the material.

\section{Sampling}

A sampling process was taken by a team of divers, who provided samples of marine sediments from all three basins and an additional sample at a reference point in Koper Bay (Figure 1). In each basin, four samples were taken at two depths (at $10 \mathrm{~cm}$ and at $100 \mathrm{~cm}$ of sediment depth), where the deepening of the basins will be carried out. Two samples were taken at a depth near the shore and two samples at a depth near the sea and two samples at a reference point in Koper Bay. A total of 56 samples with a total volume of 300 litres were analysed [23].

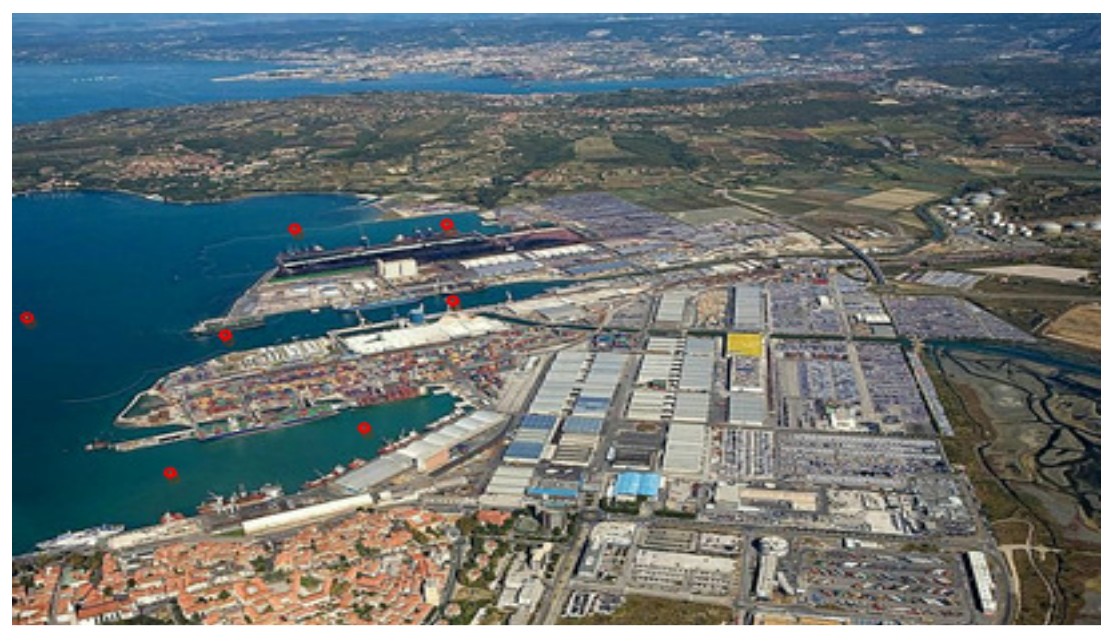

Figure 1. Red dots represent the sampling points in the Port of Koper [23] 
To avoid contamination of the samples, and to prevent changes in the specific physical and chemical properties of the samples during transport and until the beginning of the chemical and physical testing, the samples were appropriately packed, marked and stored [23].

\section{Methods}

A range of analyses were conducted in order to determine if the marine sediment containing larger quantities of clay was suitable for brick production.

In accordance with the practice in the brick industry, this phase included the following tests:

- A chemical analysis for evaluation of Silicon dioxide $\left(\mathrm{SiO}_{2}\right)$, Aluminium oxide $\left(\mathrm{Al}_{2} \mathrm{O}_{3}\right)$, Ferric oxide $\left(\mathrm{Fe}_{2} \mathrm{O}_{3}\right)$, Calcium oxide $(\mathrm{CaO})$, Magnesium oxide $(\mathrm{MgO})$, Sodium oxide $\left(\mathrm{Na}_{2} \mathrm{O}\right)$, Potassium oxide $\left(\mathrm{K}_{2} \mathrm{O}\right)$, Titanium dioxide $\left(\mathrm{TiO}_{2}\right)$ content, by means of ARL 8480S X ray fluorescence spectrometry (WD XRF);

- A mineralogical analysis was performed using Philips Norelco equipment for $\mathrm{X}$-ray diffraction analysis with $\mathrm{CuK} \alpha$ radiation and a nickel filter;

- A particle size analysis was performed by the wet sieving method;

- The Chloride content $\left(\mathrm{Cl}^{-}\right)$was determined according to EN 196 2:2013 [24].

Furthermore, the following ceramic technological tests of clay were carried out. Test samples were shaped using a laboratory de-airing extruder at a vacuum of $0.82-0.85 \mathrm{~kg} / \mathrm{cm}^{2}$. The following shapes were obtained: cylinders, prisms and tiles. Test specimens were dried for 7 days at ambient room conditions, followed by 24 hours at $60{ }^{\circ} \mathrm{C}$ and 8 hours at $100{ }^{\circ} \mathrm{C}$ in a dryer. Dried samples were then fired using heating rates of $100{ }^{\circ} \mathrm{C} / \mathrm{h}$ up to $950{ }^{\circ} \mathrm{C}$ or $1,100{ }^{\circ} \mathrm{C}$ with the holding time at the maximum temperature of 2 hours. The samples were then cooled in the furnace. Determination of linear shrinkage, water absorption, compressive and flexural strength of samples fired at selected temperatures was performed. The test of resistance to freezing of the obtained bricks (samples) was performed according to EN 539-2:2013 [25].

\section{RESULTS AND DISCUSSION}

When assessing dredging material or any other material regarding their suitability to be used in clay based sector, at first the basic properties like mineralogical and chemical compositions, as well as their particle size distribution should be determined, but equally important is how the selected material behaves when undergoing the process of shaping, drying and firing and finally what properties exhibit after firing. All these tests were performed on dredged sediment from Port of Koper.

\section{Basic analysis}

The chemical analysis of samples (see Table 1) indicates minor variations between individual basins as well as between samples taken near the surface and at depth in the sea. These minor variations are expected for natural raw materials. There were slightly larger variations in composition when comparing the results for Koper Bay with the results for individual basins. In the sample from Koper Bay, lower $\mathrm{SiO}_{2}$ content and higher carbonates content are noticeable. Furthermore, the results closely match the results of X-ray analysis (Figure 2) that also show a lower content of $\mathrm{SiO}_{2}$ and a higher content of carbonates for the sample from Koper Bay.

The results of X-ray diffraction are given in Figure 2. The mineralogical composition of clays and sediments provides an important piece of information in the process of identifying the raw material composition, because the properties of clay and, in particular, the shaping, drying and firing processes depend more on the minerals present in the raw material than on the chemical composition of the material. The content of clay 
particles in brick clay may vary from $20 \%$ to $60 \%$, but it usually amounts to $30 \%$. The clay examined contains about $55 \%$ to $63 \%$ clay particles. The minerals in the clay belong to the chlorite illite group.

Table 1. Average chemical analysis of samples taken at Port of Koper

\begin{tabular}{ccccc}
\hline Sample & Basin 1 & Basin 2 & Basin 3 & Bay of Koper \\
\hline Component & Mass [\%] & Mass [\%] & Mass [\%] & Mass [\%] \\
\hline $\mathrm{SiO}_{2}$ & 47.17 & 47.43 & 45.55 & 42.05 \\
$\mathrm{Al}_{2} \mathrm{O}_{3}$ & 12.61 & 11.49 & 12.37 & 11.20 \\
$\mathrm{Fe}_{2} \mathrm{O}_{3}$ & 4.95 & 4.23 & 4.81 & 3.99 \\
$\mathrm{CaO}$ & 10.77 & 10.99 & 10.67 & 14.34 \\
$\mathrm{MgO}$ & 2.34 & 2.18 & 2.83 & 2.76 \\
$\mathrm{Na} O$ & 1.69 & 1.89 & 1.87 & 1.84 \\
$\mathrm{~K}_{2} \mathrm{O}$ & 2.07 & 1.50 & 1.98 & 1.38 \\
$\mathrm{TiO}_{2}$ & 0.57 & 0.54 & 0.56 & 0.47 \\
$\mathrm{LOI}^{*}\left(\right.$ at $\left.950{ }^{\circ} \mathrm{C}\right)$ & 15.38 & 17.32 & 16.93 & 19.76 \\
\hline
\end{tabular}

"Loss on ignition

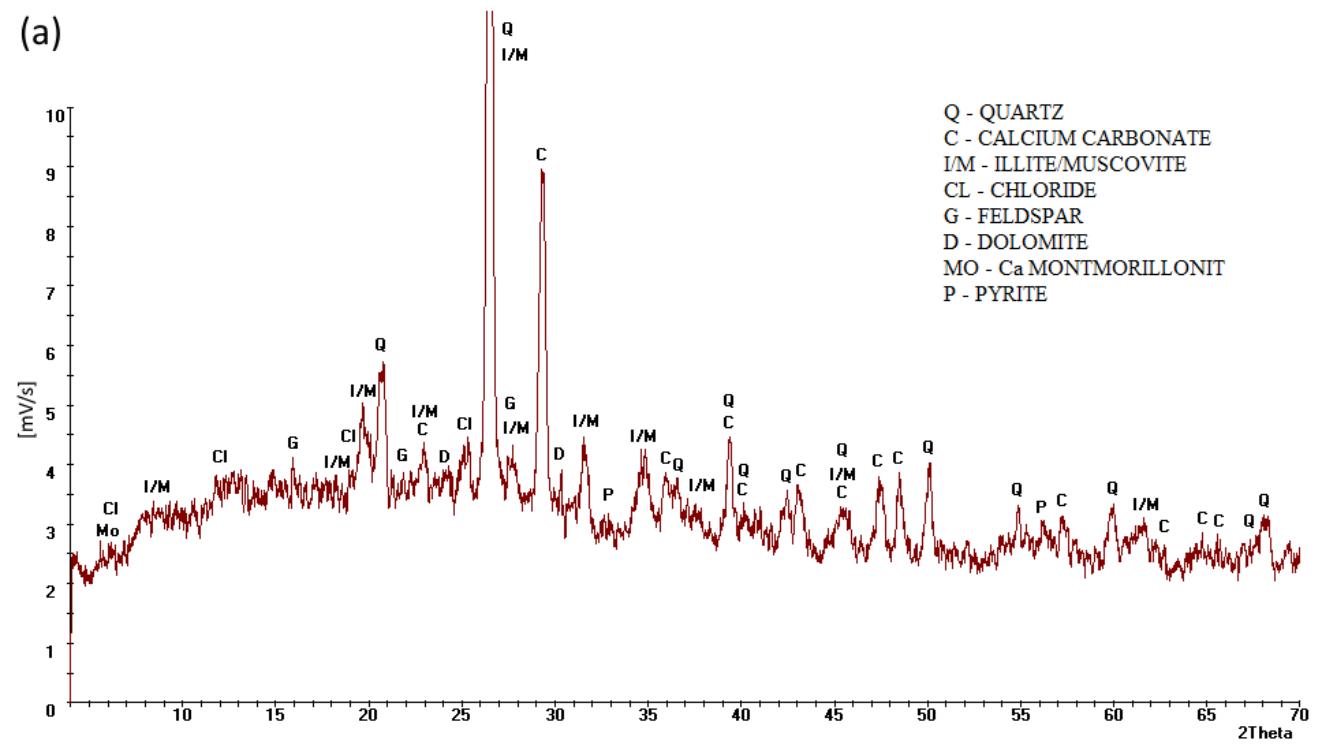

(b)

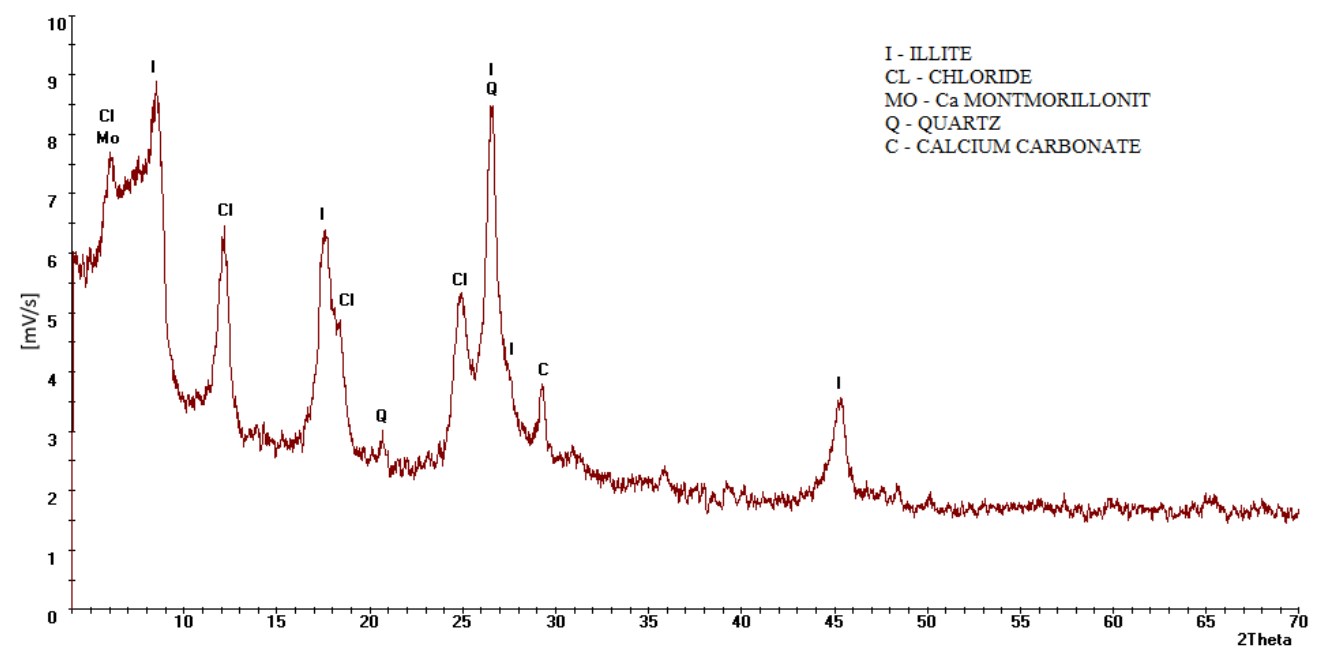

Figure 2. Typical diffractogram of the sample from "Basin 1" (a); with an additional diffractogram of fraction below $2 \mu \mathrm{m}$ (b) 
Another important factor is the amount of quartz. In clays it is present as fine sand and its content in brick clay is usually between $20 \%$ and $50 \%$. This fact is important as quartz affects the product properties as well as the drying process (reduces the sensitivity) and the firing process, where during the cooling process it is necessary to consider the phase transition of quartz at $573{ }^{\circ} \mathrm{C}$, which is connected to volume changes and may lead to cracking if the cooling process is not properly controlled. As the X-ray analysis of a sample shows, the clay tested contains about $7 \%$ to $20 \%$ quartz, comparing all the samples taken, the samples from the Port of Koper contain the lowest amounts of quartz but considerably higher amounts of calcite and dolomite.

If carbonates are finely dispersed, their content may reach up to $20-25 \%$, but a problem may arise with lime inclusions larger than $1 \mathrm{~mm}$. There is no sign of lime inclusions exceeding $1 \mathrm{~mm}$ in the clay examined, the carbonate content ranges from $15 \%$ to $19 \%$ in Basin 1 to about $29 \%$ in the Koper Bay. If lime inclusions (as free lime - CaO) are bigger than $1 \mathrm{~mm}$ in the clay body and it they are near the surface of the brick unit, white burst or pop outs can be formed as the free lime hydrates and becomes Calcium hydroxide $\left[\mathrm{Ca}(\mathrm{OH})_{2}\right]$. This reaction results in a volume increase. Exposure to air and consequently to Carbon dioxide $\left(\mathrm{CO}_{2}\right)$ in the air, further forms Calcium carbonate $\left(\mathrm{CaCO}_{3}\right)$. If the quantity is not very high, this does not impair the product quality but may be disturbing from the aesthetic point of view.

The particle size distribution in the raw material also has a significant effect on the properties of clay during the shaping, drying and firing processes as well as on the properties of dry and fired products. The results of the particle size analysis are given in Figure 3.

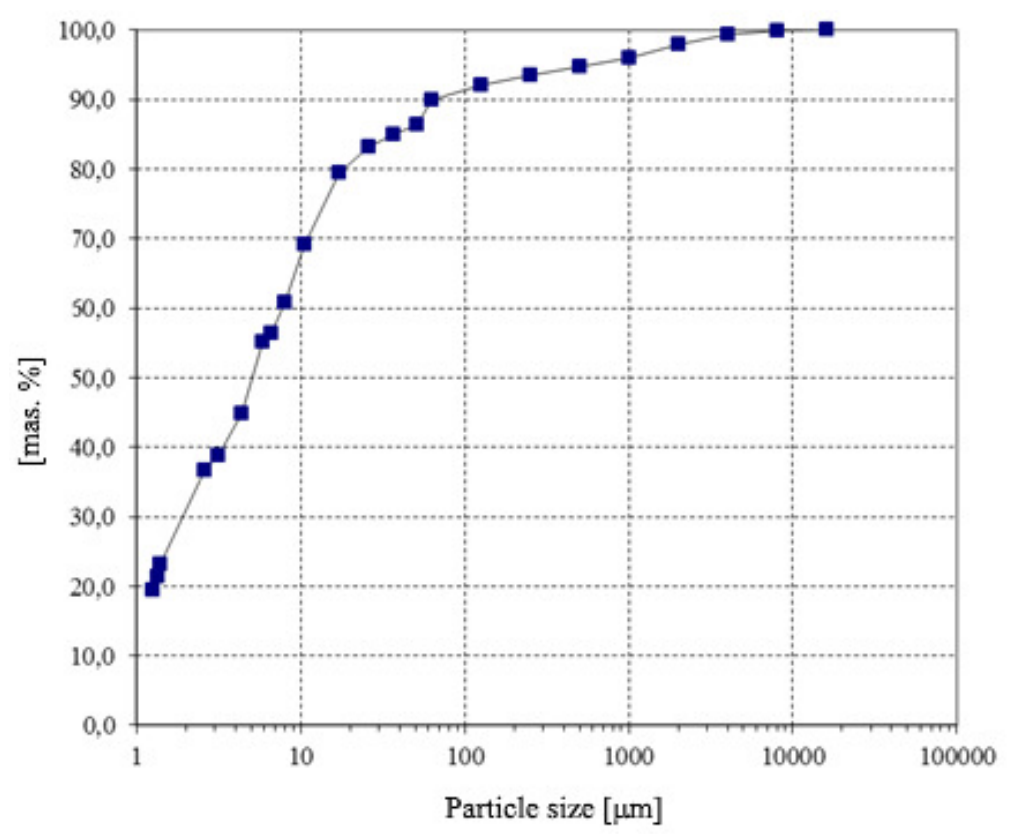

Figure 3. Particle size distribution for the sample "Basin 1"

All the tested parameters show great similarity to the typical clay used for brick production and they are also similar to the properties of some other dredged sediments [15], only the chloride content is high, which might cause problems during firing due to the corrosion of equipment and the presence of chlorine in flue gases. The chloride content was $1.6 \%$ in a non-fired/wet state. Water soluble chlorides are still present $(0.6 \%)$ when firing at a lower temperature $\left(950{ }^{\circ} \mathrm{C}\right)$, the chloride content drops after firing at temperatures above $1,050{ }^{\circ} \mathrm{C}$, their level is only $0.036 \%$ (for reference, the limit for chlorides in cements is $0.1 \%$ according to SIST EN 196 1:2005). 


\section{Ceramic technological testing of marine sediments}

The samples were prepared using a vacuum (de-airing) extruder for making tiles with dimensions of $50 \times 20 \times 8 \mathrm{~mm}$.

The analysis of the firing process in a gradient furnace provides information about linear shrinkage and water absorption as a function of the firing temperature (shown in Table 2 and Figure 4) and shows how likely it is for the clay to deform within a specific range of firing temperatures. Results of firing in a gradient furnace suggested that the examined clay is a highly sensitive type of raw material because it "closes" very quickly at temperatures exceeding $1,070{ }^{\circ} \mathrm{C}$. This means that as the firing temperature rises, the water absorption quickly drops while the shrinkage increases. When firing at about $1,150{ }^{\circ} \mathrm{C}$, clay is vitrified because the water absorption falls below $1 \%$. The clinker point (water absorption $6 \%$ ) is at $1,112{ }^{\circ} \mathrm{C}$ while the sintering point (water absorption $2 \%$ ) is at $1,143{ }^{\circ} \mathrm{C}$.

Further on, material from Basins 1 and 3 was dried and homogeneously mixed. The sample from the Basin 2 was excluded because it was polluted (there is an impact of the Rižana River that can be polluted by external influences, such as factory and septic tank emissions in the river, agriculture, etc.)

Results on the conditions of shaping and the characteristics of clay after firing and drying are given in Table 3 .

Table 2. Shrinkage and water absorption in relation to firing temperature

\begin{tabular}{ccc}
\hline Temperature $\left[{ }^{\circ} \mathrm{C}\right]$ & Shrinkage [\%] & Absorption [\%] \\
\hline 785 & 0.5 & 23.7 \\
829 & -0.1 & 24.0 \\
876 & -0.6 & 24.6 \\
918 & -0.6 & 24.5 \\
967 & 0.1 & 24.6 \\
1,020 & -0.1 & 24.6 \\
1,065 & 0.6 & 23.0 \\
1,114 & 7.6 & 5.4 \\
1,152 & 11.0 & 0.9 \\
\hline$T_{\text {clinker }}\left[{ }^{\circ} \mathrm{C}\right]$ & \multicolumn{3}{|}{1,112} \\
$T_{\text {sinter }}\left[{ }^{\circ} \mathrm{C}\right]$ & \multicolumn{3}{c}{1,143} \\
\hline
\end{tabular}

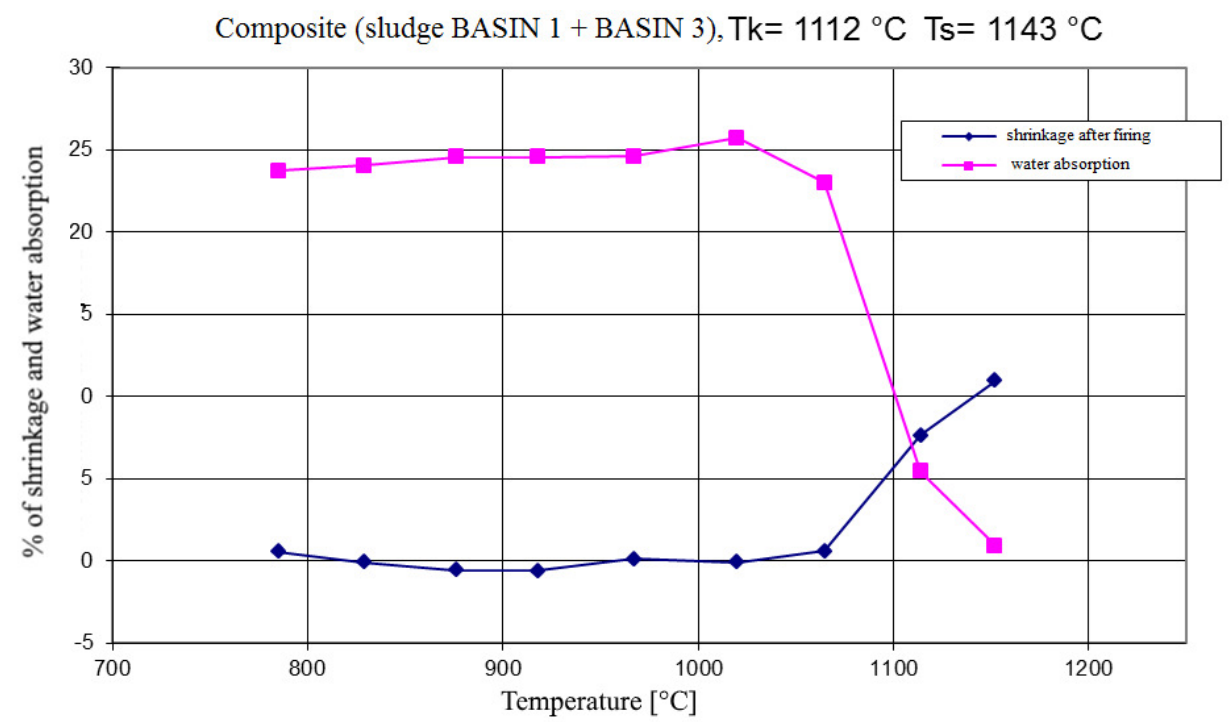

Figure 4. Shrinkage and water absorption in relation to firing temperature 
The final properties of dried and fired products deviate from the expected values for typical brick clay. Drying shrinkage especially is very high, about $12 \%$ (depending on the orientation during shaping). The products fired at $950{ }^{\circ} \mathrm{C}$ and $1,050{ }^{\circ} \mathrm{C}$ also have high water absorption (23.1 and 22.6 respectively), when fired at $1,100{ }^{\circ} \mathrm{C}$ the water absorption drops to $7 \%$, but these samples tend to bend and inflate. The values of compressive and flexural strength are satisfactory and the compressive strength amounts to $25.7 \mathrm{MPa}$ and $36.4 \mathrm{MPa}$, and the bending strength 3.2 and 8.7 when fired at $950{ }^{\circ} \mathrm{C}$ and $1,050{ }^{\circ} \mathrm{C}$, respectively. Both strengths significantly increased when fired at $1,100{ }^{\circ} \mathrm{C}$, the bending strength was $19.3 \mathrm{MPa}$ and the compressive strength was $96.8 \mathrm{MPa}$.

Frost resistance is important when products are to be exposed to severe climatic conditions. For clay products this is usually the case for outward facing bricks or clay roofing tiles, these products have to guarantee resistance to freezing [26]. Testing the frost resistance of laboratory samples has shown that the material is resistant to frost when fired at $1,100{ }^{\circ} \mathrm{C}$ but non-resistant to frost when fired at $950{ }^{\circ} \mathrm{C}$ and $1,050{ }^{\circ} \mathrm{C}$. When fired at lower temperatures water absorption is still high and this greatly contributes to the frost non-resistance.

Table 3. The conditions of shaping the specimens and the characteristics of clay after firing and drying

\begin{tabular}{|c|c|c|c|}
\hline Description of the sample & & Composite & \\
\hline \multicolumn{4}{|l|}{ Forming } \\
\hline Vacuum $\left[\mathrm{kg} / \mathrm{cm}^{2}\right]$ & & $0.82-0.85$ & \\
\hline No. according to Pfefferkorn & & 3.08 & \\
\hline$\%$ moisture based on dry mass & & 41.0 & \\
\hline$\%$ moisture based on wet mass & & 29.1 & \\
\hline \multicolumn{4}{|l|}{ Shrinkage with drying [\%] } \\
\hline Measured along the prism length & 12.0 & 12.0 & 12.4 \\
\hline Measured across the prism width & 11.8 & 12.0 & 11.9 \\
\hline Firing temperature $\left[{ }^{\circ} \mathrm{C}\right]$ & $950 \pm 10$ & $1,050 \pm 10$ & $1,100 \pm 10$ \\
\hline \multicolumn{4}{|l|}{ Shrinkage after firing [\%] } \\
\hline Measured along the prism length & 0.5 & 0.7 & 6.4 \\
\hline Measured across the prism width & 0.4 & 1.0 & 9.2 \\
\hline Water absorption [\%] & 23.1 & 22.6 & 7.0 \\
\hline \multicolumn{4}{|l|}{ Prism } \\
\hline Loss of mass [\%] & 15.5 & 17.4 & 15.8 \\
\hline \multicolumn{4}{|l|}{ Prism } \\
\hline Bending strength [MPa] & 3.2 & 8.7 & 19.3 \\
\hline \multicolumn{4}{|l|}{ Prism } \\
\hline Density $\left[\mathrm{g} / \mathrm{cm}^{3}\right]$ & 1.5 & 1.6 & 2.0 \\
\hline \multicolumn{4}{|l|}{ Prism } \\
\hline Compressive strength [MPa] & 25.7 & 36.4 & 96.8 \\
\hline Cylinder & & & \\
\hline
\end{tabular}

To improve the brick production process and to achieve optimal properties in the technological process of shaping ceramic products, further studies have to be carried out using possible additions that reduce plasticity and the drying shrinkage. Suitable additions could include waste material containing quartz such as silica sludge, or slag $[18,27]$. The sediments from the Port of Koper contain large amounts of water (more than $70 \%$ ) and therefore have to be dried beforehand. For this reason it is best to find a dry additive, for example paper sludge [16] or fly ash because it facilitates the regulation of the water content needed in the shaping process [17]. 


\section{CONCLUSIONS}

In order to find a solution for the dredge sediment, in this case sediment from Port of Koper, analyses were performed to evaluate it as a potential raw material for the clay brick sector, which constantly searches for materials that could adequately replace virgin raw materials.

On the basis of the primary analyses and samples prepared in a laboratory, it can be argued that the sediments without any additives are only conditionally suitable as source material for brick production. The major problem arises with excessive drying shrinkage, which amounts to about $12 \%$ (the usual shrinkage with brick clay is below 3-4\%) and high water absorption. In order to ensure water absorption below $20 \%$ (which is normal for protected/plastered bricks) or below $6 \%$ (which is normal for bricks directly exposed to weather conditions), the firing process has to be carried out at higher temperatures and within a limited temperature range, which is quite difficult to provide in industrial conditions.

Improvements in shaping, drying and properties of fired products could be achieved by including suitable additives, like virgin clay or some clay-based waste material, which will be the subject of further research. Approaches that would lower the salt (chloride) content will also be examined and its influence on the production process as well as on the final product will also be carefully studied.

The presented methodology can be also applied to sediments from other ports and rivers in order to assess their potential use in clay brick sector. Namely, preserving natural resources and instead using wastes is in line with national and European sustainability requirements expressed through the circular economy approach.

\section{REFERENCES}

1. Dubois, V., Abriak, N. E., Zentar, R. and Ballivy, G., The use of Marine Sediments as a Pavement Base Material, Waste Management, Vol. 29, No. 2, pp 774-782, 2009, https://doi.org/10.1016/j.wasman.2008.05.004

2. Missaoui, S., Said, I., Zelleg, M., Hamdi, E. and Lafhaj, Z., Correlations between Sediments Characteristics from Tunisian Harbours (Singh, D. N. and Galaa, A., eds), Contemporary Issues in Geoenvironmental Engineering and Sustainable Civil Infrastructure, Springer International Publishing AG, Basel, Switzerland, 2018.

3. Mymrin, V., Stella, J. C., Scremim, C.-B., Pan, R. C. Y., Sanchez, P. G., Alekseev, K., Pedroso, D. E., Molinetti, A. and Fortini, O., Utilization of Sediments dredged from Marine Ports as a Principal Component of Composite Material, Journal of Cleaner Production, Vol. 142, Part 2, pp 4041-4049, 2016, https://doi.org/10.1016/j.jclepro.2016.10.035

4. Couvidat, J., Benzaazoua, M., Chatain, V., Bouamrane, A. and Bouzahzah, H., Feasibility of the reuse of Total and Processed Contaminated Marine Sediments as Fine Aggregates in Cement Mortars, Construction and Building Materials, Vol. 112, pp 892-902, 2016, https://doi.org/10.1016/j.conbuildmat.2016.02.186

5. Krašovec, L., Report on Environmental Impact Assessment in the Process of Pool Refill with the dredged Sediment in the Ankaranska Bonifika Area (in Slovenian), Project Number gp-pr-014/12, Geoportal Internal Source of Port of Koper, 2012.

6. Akcil, A., Erust, C., Ozdemiroglu, S., Fonti, V. and Beolchini, F., A Review of Approaches and Techniques used in Aquatic Contaminated Sediments; Metal removal and stabilization by Chemical and Biochemical Processes, Journal of Cleaner Production, Vol. 86, pp 24-36, 2015, https://doi.org/10.1016/j.jclepro.2014.08.009

7. Cappuyns, V., Deweirt, V. and Rousseau, S., Dredged Sediments as a Resource for Brick Production: Possibilities and Barriers from Consumers' Perspective, Waste Management, Vol. 38, pp 372-380, 2015, https://doi.org/10.1016/j.wasman.2014.12.025 
8. Limeira, J., Etxeberria, M., Agullo, L. and Molina, D., Mechanical and Durability Properties of Concrete made with dredged Marine Sand, Department for Construction Engineering, Polytechnic University of Catalonia, Barcelona, Spain, 2010.

9. Said I., Missaoui, A. and Lafhaj, Z., Reuse of Tunisian Marine Sediments in paving Blocks, Factory Scale Experiment, Journal of Cleaner Production, Vol. 102, pp 66-77, 2015, https://doi.org/10.1016/j.jclepro.2015.04.138

10.Yozzo, D. J., Wilber, P. and Will, R. J., Beneficial use of dredged Material for Habitat Creation, Enhancement, and Restoration in New York - New Jersey Harbor, J. Environ. Manage., Vol. 73, No. 1, pp 39-52, 2004, https://doi.org/10.1016/j.jenvman.2004.05.008

11.SKM 2013, Improved Dredge Material management for the Great Barrier Reef Region, Great Barrier Reef Marine or J. Env. Park Authority, Townsville, Australia, 2013.

12.Li, M., Cong, X., Zhu, L., Kong, L., Zhang, Z., Tian, A. and Li., L., Experimental Study on recycling Dredged Marine Sediment and Phosphate tailing to produce Earth Fill, Marine Georesources and Geotechnology, Vol. 35, No. 4, pp 586-591, 2016, https://doi.org/10.1080/1064119X.2016.1213340

13.Lindsay, A. M., Dredged Material as a Resource, Terra et Aqua, Vol. 112, pp 3-12, 2008.

14.Sheehan, C., Management of Dredge Material in the Republic of Ireland - A Review, Waste Management, Vol. 32, No. 5, pp 1031-1044, 2012, https://doi.org/10.1016/j.wasman.2011.11.014

15.Gal an-Arboledas, R. J., Alvarez de Diego, J., Dondi, M. and Salvador Bueno, S., Energy, Environmental and Technical assessment for the Incorporation of EAF Stainless Steel Slag in Ceramic Building Materials, Journal of Cleaner Production, Vol. 142, Part 4, pp 1778-1788, 2017, https://doi.org/10.1016/j.jclepro.2016.11.110

16.Cusidó, J. A., Cremades, L. V., Soriano, C. and Devant, M., Incorporation of Paper Sludge in Clay Brick Formulation: Ten Years of Industrial Experience, Appl. Clay Sci., Vol. 108, pp 191-198, 2015, https://doi.org/10.1016/j.clay.2015.02.027

17.Monteiro, S. N. and Vieira, C. M. F., On the Production of Fired Clay Bricks from Waste Materials: A Critical Update, Construction and Building Materials, Vol. 68, pp 599-610, 2014, https://doi.org/10.1016/j.conbuildmat.2014.07.006

18.Mazen, S., Zoubeir, L. and Christophe, C., Valorization of Stabilized River Sediments in fired Clay Bricks, Factory Scale Experiment, Journal of Hazardous Materials, Vol. 163, No. 2-3, pp 701-710, 2009, https://doi.org/10.1016/j.jhazmat.2008.07.153

19.Mezencevova, A., Yeboah, N. N., Burns, E. S., Kahn, L. K. and Kurtisk, E., Utilization of Savannah Harbor River Sediment as the Primary Raw Material in Production of Fired Brick, Journal of Environmental Management, Vol. 113, pp 128-136, 2012, https://doi.org/10.1016/j.jenvman.2012.08.030

20.Xu, Y., Changhong, Y., Baotian, X., Xiaohong, R. and Zhi, W. The use of Urban River Sediments as a Primary Raw Material in the Production of highly Insulating Brick, Ceramics International, Vol. 40, No. 6, pp 8833-8840, 2013, https://doi.org/10.1016/j.ceramint.2014.01.105

21.Cappuyns, V., Deweirt, V. and Rousseau, S., Dredged Sediments as a Resource for Brick Production: Possibilities and Barriers from a Consumer' Perspective, Waste Management, Vol. 38, pp 372-380, 2015, https://doi.org/10.1016/j.wasman.2014.12.025

22.Sullivan, C., Tyrer, M., Cheeseman, C. R. and Graham, N. J. D., Disposal of Water treatment Wastes Containing Arsenic - A Review, Science of the Total Environment, Vol. 408, No. 8, pp 1770-1778, 2010, https://doi.org/10.1016/j.scitotenv.2010.01.010

23.Justin, B., Rožič, V., Šešerko, M., Kugonič, V. N., Ducman, V. and Fonda, L., A Study on the impact of Marine Spills into the Sea on the Quality of Marine Sediments (in Slovenian), Project Number DP59/08/14, 2014.

24.EN 196-2:2013: Method of testing Cement, Chemical Analysis of Cement. 
25.EN 539-2:2013: Clay roofing Tiles for discontinuous laying, determination of Physical Characteristics, Test for Frost Resistance.

26.Ducman, V., Sever Škapin, A., Radeka, M. and Ranogajec, J., Frost Resistance of Clay roofing Tiles: Case Study, Ceramics International, Vol. 37, No. 1, pp 85-91, 2010, https://doi.org/10.1016/j.ceramint.2010.08.012

27.Zhang, L., Production of Bricks from Waste Materials - A Review, Construction and Building Materials, Vol. 47, pp 643-655, 2013, https://doi.org/10.1016/j.conbuildmat.2013.05.043 